Turkish Online Journal of Qualitative Inquiry (TOJQI)

Volume 9, Issue 4, October 2018: 373-388

DOI: $10.17569 /$ tojqi. 417537

Research Article

\title{
Analysis of Middle School Students' Views on Scientific Inquiry in the Context of Science Achievement ${ }^{1}$
}

\author{
Zeynep Koyunlu Ünlü
}

\begin{abstract}
One of the aims of science teaching is to ensure that students enjoy scientific work and develop scientific thinking and associated inquiry skills. Scientific inquiry represents a process that scientists routinely use in their work, and it is a way for students to acquire scientific knowledge and develop scientific skills. Providing students with ample knowledge and necessary skills related to daily life, scientific inquiry is an important part of science education. This study aimed to elicit the views of a group of middle school students concerning scientific inquiry. Twenty-eight students (10 girls, 18 boys) attending the eighth grade participated in this case study. The data were collected through the Views of Scientific Inquiry (VOSI) and the students' scores in the Examination for the Transition from Primary to Secondary Education (TEOGS) held in Turkey. The relationship between TEOGS scores and student views classified by VOSI was examined. The results revealed that students that are successful in academic terms may have insufficient views of some components of scientific inquiry.
\end{abstract}

Keywords: Science teaching, science education, scientific inquiry, middle school students, student views

\footnotetext{
${ }^{1}$ The initial findings of the study were presented at the "17 $17^{\text {th }}$ Classroom Teaching Education Symposium" held in Turkey on 11-14th April 2018.

${ }^{2}$ Asst.Prof.Dr., Bozok University, Faculty of Education, Department of Elementary Education, zeynepko.unlu@gmail.com, https://orcid.org/0000-0003-3627-1809
}

Received: 20.04.2018 Accepted: 29.10.2018 


\title{
Ortaokul Öğrencilerinin Bilimsel Araştırmaya Yönelik Görüşlerinin Fen Başarısı Bağlamında İncelenmesi
}

\begin{abstract}
$\ddot{O} z$
Öğrencilerin bilimsel çalışmalardan zevk almalarını sağlamak, bilimsel düşünebilme ve bilimsel araştırma becerilerini geliştirmek fen öğretiminin amaçlarındandır. Bilimsel araştırma, bilim insanlarının çalışmalarında rutin olarak kullandığı bir süreci temsil eder ve öğrencilerin bilimsel bilgileri öğrenmelerini, bilimsel becerileri kazanmalarını sağlayan bir yöntemdir. Öğrencilere günlük yaşamla ilgili pek çok bilgi ve beceriyi kazandıran bilimsel araştırma, fen eğitiminin önemli bir parçasıdır. $\mathrm{Bu}$ araştırmanın amacı bir grup ortaokul öğrencisinin bilimsel araştırmaya yönelik görüşlerini tespit etmektir. Durum çalışması olarak yürütülen bu araştırmaya, 8. sınıfta öğrenim gören 28 öğrenci (10 kız, 18 erkek) katılmıştır. Veriler Bilimsel Sorgulama Hakkındaki Görüş Anketi (VOSI) ve Temel Eğitimden Ortaöğretime Geçiş Sınavı (TEOGS) puanları aracılığı ile toplanmıştır. VOSI ile sınıflandırılan öğrenci görüşlerinin TEOGS puanları ile ilişkisi incelenmiştir. Sonuç olarak akademik anlamda başarılı öğrencilerin de bilimsel araştırmanın bazı bileşenleri konusunda yetersiz görüşlere sahip olabileceği bulgusuna ulaşılmıştır.
\end{abstract}

Anahtar Sözcükler: Fen eğitimi-öğretimi, bilimsel araştırma, ortaokul öğrencileri, öğrenci görüşleri 


\section{Introduction}

In the past, science was considered as a piece of information that had to be directly transferred to students. However, as a result of the developments in science and technology, the application dimension of science has gained value, and thus inquiry-based learning with the underlying philosophy of progressivism (pragmatism) has emerged (Barrow, 2006). According to progressivism, the ultimate goal of education is individual development within the experience acquired. This philosophy adopts an individual or student-centered approach to education and advocates guiding students to solve problems based on their interests and needs rather than waiting for a distant future, thus opposing the idea that school means preparing for life (Cevizci, 2011).

The history of science education in Turkey reveals progress from the classical approach to constructivism. In particular, after 2005, inquiry-based learning came into prominence in the science curricula [Ministry of National Education-Turkish Education Board (MoNE-TEB), $2005,2013,2018)$. Inquiry refers to an active process in science education, involving scientific thinking, research and structuring of knowledge. It also guides the setting of goals and choice of teaching methods and learning techniques (Dojman, 2003). Inquiry encompasses a process that includes questioning, exploring, and rigorously testing discoveries to understand the natural world (de Jong, 2006). Scientific inquiry, which is part of inquiry-based learning, is defined as the method for acquiring skills, knowledge and teaching (Bybee, 2002). In other words, scientific inquiry is a scientific method or activities that represent the characteristics of the scientific process (Yang, Park, Shin, \& Lim, 2017).

A review of the literature shows that the measurement instruments proposed to be used in the area of scientific inquiry (Lederman, Lederman, Bartos, Bartels, Meyer, \& Schwartz, 2014) and studies conducted on scientific inquiry (Anggraeni, Adisendjaj, \& Amprasto, 2017; Galano, Alessandro, Luigi, \& Italo, 2016; Leblebicioğlu, Çapkınoğlu, Metin, \& Schwartz, 2017; Şenler, 2015; Yang, Park, Shin, \& Lim, 2017) are limited in number. In many studies the Views of Scientific Inquiry (VOSI-N) questionnaire developed by Lederman et al. (2014) was used usually as the data collection tool to elicit views concerning scientific inquiry. This questionnaire aims to reveal the participants' views on the following eight components of scientific inquiry (Lederman et al., 2014, p. 68): 
1. scientific investigations all begin with a question and do not necessarily test a hypothesis,

2. there is no a single set or sequence of steps followed in all investigations,

3. inquiry produces are guided by the question asked,

4. all scientists performing the same procedures may not get the same results,

5. inquiry procedures can influence the results,

6. research conclusions must be consistent with the data collected,

7. scientific data are not the same as scientific evidence,

8. explanations are developed from combination of collected data and what is already known.

Based on the participants' responses to the items in this questionnaire, their views were classified under the categories of "unclear / N/A", "naïve", "mixed" and "informed". According to their aim, studies that used VOSI as a data collection tool can be divided into two groups: (1) determining a group's views of scientific inquiry and (2) identifying changes in a group's views of scientific inquiry through certain activities. An example of the first group was a study conducted with 32 high school students at the 11th grade, a group of participants were found to be knowledgeable about research methods and questions whereas some students were not able to establish a relationship between the nature of scientific inquiry and the questions. There were also participants that did not understand the relationship between evidence and data, reason for choosing a method, or the relationship between result and data collection (Anggraeni, Adisendjaja, \& Amprasto, 2017). Within the scope of another research, 25 science teachers participated in a month-long program lasting about 30 hours and covering the nature of science and scientific inquiry subjects. It was found that before the program, most of the participant science teachers did not have a good understanding of scientific inquiry, but there was improvement, albeit small, in their views of scientific inquiry after the program (Adisendjaja, Rustaman, Redjeki, \& Satori, 2017). In another study that aimed to elicit the scientific inquiry views of high school students in Turkey, the participants had favorable views on the dimensions of "all scientific research starts with a question and does not always test a hypothesis", "there is not a single scientific method that can be followed in all studies", "scientific data and scientific evidence are not the same", and "deductions are made based on the collected data and prior knowledge"; however, their views on "scientists who follow the same procedure may not achieve the same results" and "the inquiry procedure affects the results" were not sufficient. The researchers concluded that the participants had more 
developed views on the items providing alternative options and suggested that this might be due to their familiarity with tests (Leblebicioğlu et al., 2017).

Galano, Alessandro, Luigi and Italo (2016) reported that short-term inquiry-based learning practices were not sufficient to teach the components of scientific inquiry. Şenler (2015) compared the scientific inquiry views of middle school students in the education system in Turkey and the United States of America. The author concluded that the American students had more advanced views of scientific inquiry in terms of "all scientific research starts with a question", "scientists use experimental data sets to answer questions", and "data and preliminary knowledge are used to answer questions". On the other hand, the Turkish students provided better explanations for the dimension of "there is no single scientific method". The researcher attributed the American students' more advanced views to the inclusion of scientific inquiry in American education programs for a longer time compared with the students in Turkey. In a survey conducted with middle school students in Korea, the participants' views on scientific inquiry were found to be complex and naive. The authors argued that this resulted from the participants' inability to fully understand the concepts of experiment, science, data and evidence. In addition, they suggested that explicit and reflective teaching can develop individuals' views of scientific inquiry (Yang, Park, Shin, \& Lim, 2017). The results of recent research also showed that explicit, inquiry-based learning improved the participants' views concerning scientific inquiry (Testa, Zappia, \& Galano, 2017).

In the 2015 International Student Assessment Program (PISA, 2015), three competencies were defined for scientific literacy: (1) explaining phenomena scientifically, (2) designing and evaluating scientific inquiry methods, and (3) interpreting data and findings scientifically (PISA, 2015). In order to be successful in PISA tests, the students must have a good understanding of the nature of scientific inquiry. The aim of science teaching is more than to teach students scientific facts and concepts; it is to help students enjoy and understand scientific work, and develop scientific thinking and inquiry skills (Bezir Akçay, 2016). Scientific inquiry is an important part of science education, providing students with the necessary knowledge and skills required in daily life. The current study aimed to examine the relationship between the academic achievements of students in the science course and their views on scientific inquiry.

\section{Methodology}


This research was conducted as a case study, which is a qualitative approach, in which the researcher puts together a variety of facts about a limited current situation in real life to describe that situation (Creswell, 2013). This study aimed to offer an insight into the academic achievements of the participant students attending a science course and their views concerning scientific inquiry. For this reason, it had an explanatory / descriptive case study design. In descriptive case studies, examples of a situation are examined to provide a descriptive definition of the situation (Davey, 1991).

\section{Participants}

Twenty-eight students (10 girls, 18 boys aged 15) attending the eighth grade of a middle school in the Central Anatolia Region of Turkey participated in this research. A purposeful sampling method was used in the selection of the participants. In this method, the units of observation can be people, phenomena, or objects from a specific situation (Patton, 2002). In this study, the situation that was explored was the students' science achievement. Table 1 presents the TEOGS scores, gender and coding of the participants.

Table 1

Participants' TEOGS Scores, Gender and Coding

\begin{tabular}{cccc}
\hline TEOGS scores & Girl & Boy & Coding \\
\hline 100 & 4 & 4 & $\mathrm{~A}_{1}, \mathrm{~A}_{2}, \mathrm{~A}_{3}, \mathrm{~A}_{4}, \mathrm{~A}_{5}, \mathrm{~A}_{6}, \mathrm{~A}_{7}, \mathrm{~A}_{8}$ \\
95 & 4 & 1 & $\mathrm{~B}_{1}, \mathrm{~B}_{2}, \mathrm{~B}_{3}, \mathrm{~B}_{4}, \mathrm{~B}_{5}$ \\
90 & 4 & - & $\mathrm{C}_{1}, \mathrm{C}_{2}, \mathrm{C}_{3}, \mathrm{C}_{4}$ \\
85 & 3 & - & $\mathrm{D}_{1}, \mathrm{D}_{2}, \mathrm{D}_{3}$ \\
75 & 2 & 1 & $\mathrm{E}_{1}, \mathrm{E}_{2}, \mathrm{E}_{3}$ \\
70 & 1 & - & $\mathrm{F}_{1}$ \\
65 & 1 & - & $\mathrm{G}_{1}$ \\
60 & 2 & - & $\mathrm{H}_{1}, \mathrm{H}_{2}$ \\
55 & 1 & - & $\mathrm{I}_{1}$ \\
\hline
\end{tabular}

As shown in Table 1, the participants' TEOGS scores were as follows: 100 points for eight participants (four girls, four boys), 95 points for five (four girls, one boy), 90 points for four girls, 85 points for three girls, 75 points for three participants (two girls, one boy), 70 points for one girl, 65 points for one girl, 60 points for two girls, and 55 points for one girl. According to their TEOGS scores, the students were coded as A for 100 points, $\mathrm{B}$ for 95 points, $\mathrm{C}$ for 90 points, $\mathrm{D}$ for 85 points, $\mathrm{E}$ for 75 points, $\mathrm{F}$ for 70 points, $\mathrm{G}$ for 65 points, $\mathrm{H}$ for 60 points, and I for 55 points. 


\section{Data Collection Tools}

In this study, the data was collected during the first semester of the 2016-2017 academic year through interviews and documents. VOSI was administered to determine the participants' views on scientific inquiry and the participants' TEOGS scores were used as documents. The data collection tools used in this research are explained in detail in the following subsections.

\section{VOSI}

In this study, the VOSI questionnaire developed by Schwartz, Lederman and Lederman (2008) was used to determine the participants' views on scientific inquiry. This questionnaire consists of five open-ended questions addressing the following six components of scientific inquiry: (1) questions guide inquiry, (2) scientific inquiry has more than one method, (3) scientific inquiry has more than one purpose, (4) scientific knowledge is justified, (5) data and evidence are not the same, and (6) science is the practice of a scientific community. Based on the participants' responses to the five items in VOSI, their views are classified as "unclear / N/A", "naive", "mixed", and "informed".

Thirty-minute structured interviews were undertaken with each of the 28 eighth-grade students that participated in the research. The interviews were conducted by the researcher in the school library with permission from the school administration and audio-recorded.

\section{TEOGS scores}

TEOGS is a central examination that was implemented by MoNE in Turkey in both school terms of the academic years 2013-2014, 2014-2015 and 2016-2017. The eighth-grade students' scores in this test determined which middle school they would attend. This test contained questions related to the subject areas of Turkish, mathematics, science, English, social studies, and religious culture. The students were presented with 20 questions with four options from each branch. The scores obtained from the correct answers were multiplied by 5 to calculate the branch score. In this study, the participants' TEOGS science scores belonging to the first term of the 2016-2017 academic year were used.

\section{Data Analysis}


The data was examined by content analysis, and in this paper, the findings are presented with excerpts from the participants' interviews. The main goal in content analysis is to establish associations that can explain the collected data. In this process, the codes used are classified under certain categories (Yıldırım \& Şimşek, 2006).

During the data analysis process, the conversations were recorded with a voice recorder. Since VOSI was used as the data collection tool, the participants' responses were classified under the categories proposed by the researchers that developed this questionnaire (Schwartz et al., 2008). Thus, the students' views related to the six components of scientific inquiry were classified and tabulated under the categories of "unclear / N/A", "naive", "mixed", and "informed". In this process, the two researchers first worked individually, and then the intercoder agreement was calculated.

\section{Validity, Reliability and Ethical Issues}

In this study, more than one data collection tool was used in order to ensure construct validity. After transcribing the audio-recorded interviews, the participants were re-interviewed to determine whether their responses were consistent and they received participant confirmation (Patton, 2002). The reliability of the categories obtained from content analysis was calculated using the following formula: "reliability $=$ number of agreements / number of agreements + disagreements" (Miles, \& Huberman, 1994, p. 64). The inter-coder agreement was calculated as $86 \%$. The participants comprised students that volunteered to take part in the study and their real names were not used.

\section{Findings}

Table 2 presents the participants' views of scientific inquiry classified under the categories of "unclear / N/A", "naive", "mixed", and "informed".

Table 2

The Participants' Views of Scientific Inquiry

\begin{tabular}{lllll}
\hline VOSI dimension & Unclear / N/A & Naive & Mixed & Informed \\
\hline
\end{tabular}




\begin{tabular}{|c|c|c|c|c|}
\hline (1) Questions guide inquiry. & $A_{3}, D_{2}, E_{1}$ & $\begin{array}{l}\mathrm{A}_{1}, \mathrm{~A}_{2}, \mathrm{~A}_{4}, \mathrm{~A}_{5}, \\
\mathrm{~A}_{6}, \mathrm{~A}_{7}, \mathrm{~A}_{8}, \mathrm{~B}_{1}, \\
\mathrm{~B}_{2}, \mathrm{~B}_{3}, \mathrm{~B}_{4}, \mathrm{~B}_{5}, \\
\mathrm{C}_{1}, \mathrm{C}_{2}, \mathrm{C}_{3}, \mathrm{C}_{4}, \\
\mathrm{E}_{3}, \mathrm{D}_{1}, \mathrm{D}_{3}, \mathrm{~F}_{1}, \\
\mathrm{G}_{1}, \mathrm{H}_{1}, \mathrm{H}_{2}, \mathrm{I}_{1}\end{array}$ & & $\mathrm{E}_{2}$ \\
\hline $\begin{array}{l}\text { (2) Scientific inquiry has more } \\
\text { than one method. }\end{array}$ & $\begin{array}{c}\mathrm{A}_{2}, \mathrm{~A}_{3}, \mathrm{~A}_{5}, \mathrm{~A}_{6}, \\
\mathrm{~A}_{8}, \mathrm{~B}_{2}, \mathrm{~B}_{3}, \mathrm{C}_{2}, \\
\mathrm{D}_{1}, \mathrm{E}_{3}, \mathrm{G}_{1}, \mathrm{H}_{1}, \\
\mathrm{H}_{2}, \mathrm{I}_{1}\end{array}$ & $\mathrm{~A}_{1}, \mathrm{~A}_{7}, \mathrm{D}_{3}, \mathrm{~F}_{1}$ & $\mathrm{C}_{4}, \mathrm{E}_{1}$ & $\begin{array}{l}\mathrm{A}_{4}, \mathrm{~B}_{1}, \mathrm{~B}_{4}, \mathrm{~B}_{5} \\
\mathrm{C}_{1}, \mathrm{C}_{3}, \mathrm{D}_{2}, \mathrm{E}_{2}\end{array}$ \\
\hline $\begin{array}{l}\text { (3) Scientific inquiry has more } \\
\text { than one purpose. }\end{array}$ & $\mathrm{D}_{2}$ & $\mathrm{~A}_{2}, \mathrm{~A}_{3}, \mathrm{~A}_{6}, \mathrm{D}_{1}$ & $\begin{array}{c}\mathrm{A}_{5}, \mathrm{C}_{3}, \mathrm{D}_{3}, \mathrm{E}_{1}, \\
\mathrm{~F}_{1}\end{array}$ & $\begin{array}{c}\mathrm{A}_{1}, \mathrm{~A}_{4}, \mathrm{~A}_{7}, \mathrm{~A}_{8}, \\
\mathrm{~B}_{1}, \mathrm{~B}_{2}, \mathrm{~B}_{3}, \mathrm{~B}_{4}, \\
\mathrm{~B}_{5}, \mathrm{C}_{1}, \mathrm{C}_{2}, \mathrm{C}_{4}, \\
\mathrm{E}_{2}, \mathrm{E}_{3}, \mathrm{G}_{1}, \mathrm{H}_{1}, \\
\mathrm{H}_{2}, \mathrm{I}_{1}\end{array}$ \\
\hline $\begin{array}{l}\text { (4) Scientific knowledge is } \\
\text { justified. }\end{array}$ & $\mathrm{A}_{1}, \mathrm{~A}_{5}, \mathrm{~A}_{8}, \mathrm{D}_{1}$ & $\begin{array}{c}\mathrm{A}_{4}, \mathrm{~A}_{6}, \mathrm{~A}_{7}, \mathrm{~B}_{3}, \\
\mathrm{C}_{4}, \mathrm{D}_{2}, \mathrm{G}_{1}, \mathrm{H}_{1}, \\
\mathrm{H}_{2}, \mathrm{I}_{1} \\
\end{array}$ & $\begin{array}{c}\mathrm{A}_{2}, \mathrm{~B}_{1}, \mathrm{~B}_{2}, \mathrm{~B}_{4} \\
\mathrm{~B}_{5}, \mathrm{D}_{3}, \mathrm{E}_{1}, \mathrm{E}_{3}, \mathrm{~F}_{1}\end{array}$ & $\begin{array}{c}\mathrm{A}_{3}, \mathrm{C}_{1}, \mathrm{C}_{2}, \mathrm{C}_{3}, \\
\mathrm{E}_{2}\end{array}$ \\
\hline $\begin{array}{l}\text { (5) Data and evidence are not } \\
\text { the same. }\end{array}$ & $\begin{array}{c}\mathrm{A}_{1}, \mathrm{~A}_{7}, \mathrm{~A}_{8}, \mathrm{~B}_{1}, \\
\mathrm{~B}_{3}, \mathrm{~B}_{5}, \mathrm{C}_{3}, \mathrm{C}_{4}, \\
\mathrm{D}_{2}, \mathrm{E}_{1}, \mathrm{E}_{3}, \mathrm{H}_{1}, \\
\mathrm{H}_{2}, \mathrm{I}_{1}\end{array}$ & $\begin{array}{l}A_{2}, A_{4}, A_{5}, A_{6} \\
C_{2}, D_{1}, F_{1}, G_{1}\end{array}$ & $\mathrm{~A}_{3}, \mathrm{~B}_{4}$ & $\mathrm{~B}_{2}, \mathrm{C}_{1}, \mathrm{D}_{3}, \mathrm{E}_{2}$ \\
\hline $\begin{array}{l}\text { (6) Science is the practice of a } \\
\text { scientific community. }\end{array}$ & $\mathrm{A}_{3}, \mathrm{D}_{2}$ & $\begin{array}{c}\mathrm{A}_{6}, \mathrm{~A}_{8}, \mathrm{~B}_{1}, \mathrm{~B}_{3}, \\
\mathrm{~B}_{4}, \mathrm{C}_{1}, \mathrm{C}_{2}, \mathrm{C}_{3}, \\
\mathrm{C}_{4}, \mathrm{D}_{1}, \mathrm{G}_{1}, \mathrm{H}_{2}, \mathrm{I}_{1}\end{array}$ & $\begin{array}{c}\mathrm{A}_{1}, \mathrm{~A}_{5}, \mathrm{~B}_{2}, \mathrm{E}_{3} \\
\mathrm{H}_{1}\end{array}$ & $\begin{array}{l}\mathrm{A}_{2}, \mathrm{~A}_{4}, \mathrm{~A}_{7}, \mathrm{~B}_{5} \\
\quad \mathrm{E}_{1}, \mathrm{E}_{2}, \mathrm{~F}_{1}\end{array}$ \\
\hline
\end{tabular}

The students' views on the six dimensions of scientific inquiry were at different levels (Table 2). It was determined that some of the students with the highest score at A level in the TEOGS science domain had unclear / N/A or naive views of scientific inquiry. Furthermore, most of the students had naive views concerning the dimension of "questions guide inquiry". Only one student that scored 75 in TEOGS was considered to hold informed views. Instead of focusing on the necessity of formulating a research question to conduct inquiry, the students gave responses, such as scientists conducted experiments, worked regularly, made observations, conducted research and administered questionnaires, read books, and followed their curiosity. These views of the students were classified under the "naïve" and "mixed" categories. Only one student scoring 75 in TEOGS science stated, "Scientists concentrate on one question and make an effort [to find an answer]".

Similarly, concerning the dimension of "scientific inquiry has more than one method", it was found that the views of the majority of successful students were in the "unclear / N/A and "naive" categories. A student who was evaluated as "informed" in this dimension explained that "Scientists who ask the same question and use the same method may not reach the same conclusions because one might make a procedural error or their interpretation might differ". A student with naive views on this issue elaborated his/her view as, "Scientists who ask the same 
question and use the same method reach the same conclusions because all the questions have a single answer". Another student scoring full marks in TEOGS stated that "If different scientists ask the same question and use different methods, they would not reach the same conclusion. This is because data is important. It can change the result if it is collected by different methods". This response was considered to be "naive".

It appears that most of the participants had "informed" views concerning the dimension of "scientific inquiry has more one purpose". However, it was observed that three students that scored 100 in TEOGS science held "naive" views in this dimension. A student who was evaluated as "informed" in this dimension of scientific inquiry mentioned that scientists may engage in various actions, such as carrying out excavations, measurements, activities, experiments, research and evaluation, drawing conclusions, and sharing the findings.

There were only a limited number of students with "informed" views in the scientific inquiry dimension of "scientific knowledge is justified". Some students did not consider knowledge obtained only by observation as scientific. For example, one student that scored 100 in TEOGS but held "naive" views in this dimension elaborated his view as follows: "I do not consider it a scientific explanation when a scientist reports that there is a relationship between birds' beaks and the varieties of food they eat because this may differ according to different species".

In relation to the scientific inquiry dimension of "Data and evidence are not the same", it was similarly seen that some participants that were evaluated as being successful in science based on their TEOGS scores held naive views, providing the response "I do not know" to the following questions: "What does data mean in science?, "What does data analysis involve?", and "Are data and evidence the same or different?". An informed student says, however, explained his/her view as "Data is gathering information and data analysis is organizing the gathered information in a regular way. Evidence is statements made based on the data collected". Another student who obtained a full score in TEOGS stated, "Data and evidence are not the same thing. Data is scientific, evidence is a clue". This view was categorized as "naive".

A student with "informed" views regarding "Science is the practice of a scientific community." commented that "Scientists conduct research to meet the needs of the society they are in; they make inventions that no one else has achieved.". One student responded "I do not know" and 
was classified under the "unclear / N/A". Another student who had a full score in TEOGS conveyed his/her views as, "Scientists first learn about the subject they want to investigate, and after thinking through it, they decide what to do. The subject under inquiry is affected by the environment in which scientists live, the climate and geographical features, the problems they encounter, and their own interests", which was categorized as an "informed" view.

\section{Discussion and Conclusion}

This study, which aimed to examine middle school students' views of scientific inquiry in the context of their academic achievements in the science course, revealed that even students that could be considered as successful in the academic sense may have inadequate views concerning some components of scientific inquiry. Many participants had naive views in the dimensions of "questions guide inquiry", "scientific knowledge is justified", and "science is the practice of a scientific community"; unclear views in "scientific inquiry has more than one method" and "data and evidence are not the same"; and informed views in "scientific inquiry has more than one purpose". This result is in agreement with the literature in terms of demonstrating that science teachers and students' views of scientific inquiry are not at a desirable level (Adisendjaja, Rustaman, Redjeki, \& Satori, 2017; Anggraeni, Adisendjaja, \& Amprasto, 2017; Galano, Alessandro, Luigi, \& Italo, 2016; Leblebicioğlu, Çapkınoğlu, Metin, \& Schwartz, 2017; Yang, Park, Shin, \& Lim, 2017; Şenler, 2015).

In this research, most of the participants were found to have naive views in the dimension of "questions guide inquiry", which is not consistent with the results of the study undertaken by Karışan, Şenler and Bilican (2017) with science teacher candidates. The authors suggested that science teacher candidates had informed views concerning this dimension due to their experience related to science. Adisendjaja, Rustaman, Redjeki and Satori (2017) considered the inability to understand the role of scientific inquiry as a misconception. Similar to our results, in their study with high school students, Anggraeni, Adisendjaja and Amprasto (2017) also reported that students did not clearly understand the role of questions in scientific inquiry. In order to carry out scientific inquiry, there is a need for questions that will guide the inquiry (Lederman et al., 2014). 
Our participants had unclear views in the dimension of "Scientific inquiry has more than one method". Testa, Zappia and Galano (2017) reached the conclusion that high school students' misconceptions related to this dimension originated from textbooks, but this can be resolved through explicit, inquiry-based learning. Similarly, in a recent study, it was reported that textbooks are not designed to improve students' ability to conduct research (Aldahmash, Mansour, Alshamrani, \& Almohi, 2016). In this respect, it is useful to examine textbooks. If science textbooks are not designed to improve students' views and skills in scientific inquiry, the teacher should provide additional guidance for students concerning the topic.

The results of the current research revealed that many participants failed to understand that data comprises sources collected to seek an answer to a research question and evidence is the interpreted form of data. Similarly, a study conducted with middle school students in Korea reported that students did not fully understand the concepts of "experiment", "data" and "evidence" (Yang et al., 2017). In light of this finding, it can be inferred that in order to improve students' views of scientific inquiry, it is necessary to ensure that they clearly and fully understand all related concepts.

\section{Suggestions}

There are studies in the literature that link naive views of scientific research with the tests adopted in the education system (Leblebicioğlu et al., 2017). For this reason, activities performed at preschool, primary school, high school and university levels and questions that are solved in class can be designed in a way to improve students' views on scientific inquiry. In this sense, the educational environment should provide students with more opportunities to conduct inquiries. There is evidence in the literature that the short-term implementation of research-inquiry activities does not develop students' scientific inquiry views (Galano et al., 2016). Therefore, such activities should be undertaken over a long period by integrating them into science classes. Textbooks can also be revised to improve students' views on scientific inquiry. Rather than test questions that limit the thinking skills of students, it is essential to engage in solving open-ended questions that require students to be involved in the thinking and interpreting processes. 
Future research can investigate the effect of scientific inquiry experiences, epistemological beliefs and various thinking skills on the scientific inquiry views of students at different grade levels. 


\section{References}

Adisendjaja, Y.H., Rustaman, N.Y., Redjeki, S., \& Satori, D. (2017). Science teachers' understanding of scientific inquiry in teacher professional development. Journal of Physics: Conference Series, 812, 1-5.

Aldahmash, A.H., Mansour, N.S., Alshamrani, S.M., \& Almohi, S. (2016). An analysis of activities in Saudi Arabian middle school science textbooks and workbooks for the inclusion of essential features of inquiry. Research in Science Education, 46, 879-900.

Anggraeni, N., Adisendjaj, Y.H., \& Amprasto, A. (2017). Profile of high school students' understanding of scientific inquiry. Journal of Physics: Conference Series, 895, 1-5.

Barrow, L.H. (2006). A brief history of inquiry: From Dewey to standards. Journal of Science Teacher Education, 17, 265-278.

Bybee, R.W. (2002). Learning science and the science of learning: science educators' essay collection. National Science Teachers Association.

Cevizci, A. (2011). Ĕ̌gitim felsefesi. İstanbul: Say.

Creswell, J.W. (2013). Qualitative inquiry \& research design choosing among five approaches. Sage Publications.

Davey, L. (1991). The application of case study evaluations. Practical Assessment, Research \& Evaluation, 2(9). 1-2.

de Jong, T. (2006). Computer simulations-technological advances in inquiry learning. Science, 312, 532-533.

Dojman, H. N. (2003). An analysis of elementary teachers' perceptions of teaching science as inquiry. Doctoral Dissertation, The Faculty of the College of Education University of Houston, Texas.

Galano, S., Alessandro, Z., Luigi, S., \& Italo, T. (2016). Secondary students' views about scientific inquiry. Retrieved January, 25, 2018 from http://www1.unipa.it/girep2014/accepted-papers proceedings/62_Galano.pdf

Jarrett, D. (1997). Inquiry strategies for science and mathematics learning it's just good teaching. Oregon: Northwest Regional Educational Laboratory. 
Johnston, J.S. (2009). Deweyan inquiry: From education theory to practice. Albany: State University of New York Press.

Karışan, D., Bilican, K., \& Şenler, B. (2017). Bilimsel sorgulama hakkında görüş anketi: Türkçeye uyarlama, geçerlik ve güvenirlik çalışması. Inönü Üniversitesi Eğitim Fakültesi Dergisi, 18(1), 326-343.

Leblebicioğlu, G., Çapkınoğlu, E., Metin, D., \& Schwartz, R. (2017). Views of nature of scientific inquiry of the students in a science high school in Turkey: a vasi application. Paper presented at ESERA, 2017.

Lederman, J.S., Lederman, N.G., Bartos, S.A., Bartels, S.L., Meyer, A.A., \& Schwartz, R. S. (2014). Meaningful assessment of learners' understandings about scientific inquiry the views about scientific inquiry (VASI) questionnaire. Journal of Research in Science Teaching, 51(1), 65-83.

Lee, H.S., \& Songer, N.B. (2003). Making authentic science accessible to students. International Journal of Science Education, 25(1), 1-26.

Lustick, D. (2009). The failure of inquiry: preparing science teachers with an authentic investigation. Journal of Science Teacher Education, 20, 583-604.

Martin-Hansen, L. (2002). Defining inquiry. The Science Teacher, 69(2), 34-37.

MEB-TTKB. (2006). Illköğretim kurumlarl (ilkokullar ve ortaokullar) fen bilimleri dersi (3, 4, 5, 6, 7 ve 8. siniflar) ögretim programı. Ankara: MEB.

MEB-TTKB. (2013). İlköğretim kurumlarl (ilkokullar ve ortaokullar) fen bilimleri dersi (3, 4, 5, 6, 7 ve 8. sinıflar)öğretim programı. Ankara: MEB.

MEB-TTKB. (2018). İlköğretim kurumlarl (ilkokullar ve ortaokullar) fen bilimleri dersi (3, 4, 5, 6, 7 ve 8. sinıflar) ögretim programı. Ankara: MEB.

Miles, M.B., \& Huberman, A.M. (1994). Qualitative data analysis. Thousand Oaks, CA: Sage. MoNE. (2015). International student assesment programme PISA national pre report. MoNe Ölçme, Değerlendirme ve Sinav Hizmetleri Genel Müdürlüğü, Ankara.

Patton. M. Q. (2002). Qualitative research and evaluation methods (3rd ed.). Thousand Oaks, CA: Sage Publications.

Sadeh, I., \& Zion, M. (2012). Which type of inquiry project do high school biology students prefer: Open or guided? Research Science Education, 42, 831-848. 
Schwartz, R.S., Lederman, N.G., \& Barbara A.C. (2004). Developing views of nature of science in an authentic context: An explicit approach to bridging the gap between nature of science and scientific inquiry. Science Teacher Education, 88(4), 610-645.

Schwartz, R.S., Lederman, N.G., \& Lederman, J.S. (2008). An instrument to assess views of scientific inquiry: The VOSI questionnaire. International Conference of the National Association for Research in Science Teaching (NARST), Baltimore, MD.

Şenler, B. (2015). Middle school students' views of scientific inquiry: an international comparative study. Science Education International, 26(2), 166-179.

Yang, I.H., Park, S.W., Shin, J.Y., \& Lim, S.M. (2017). Exploring Korean middle school students' view about scientific inquiry. Eurasia Journal of Mathematics Science and Technology Education, 13(7), 3935-3958. 